Case Reports in
Gastroenterology
Case Rep Gastroenterol 2020;14:702-706

DOI: $10.1159 / 000511251$

Published online: December 16, 2020

(C) 2020 The Author(s)

Published by S. Karger AG, Basel www.karger.com/crg

This article is licensed under the Creative Commons Attribution-NonCommercial 4.0 International License (CC BY-NC) (http://www.karger.com/Services/OpenAccessLicense). Usage and distribution for commercial purposes requires written permission.

\title{
Diffuse Esophageal Squamous Papillomatosis: A Rare Disease Associated with Acanthosis Nigricans and Tripe Palms
}

\author{
Tanyaporn Chantarojanasiri Arunluk Buranathawornsom \\ Apichet Sirinawasatien \\ Division of Gastroenterology, Department of Medicine, Rajavithi Hospital, College of \\ Medicine, Rangsit University, Bangkok, Thailand
}

\section{Keywords}

Acanthosis nigricans · Tripe palms · Esophageal squamous papilloma - Diffuse esophageal papillomatosis

\begin{abstract}
Acanthosis nigricans with tripe palms is one of the skin manifestations of systemic conditions, as well as internal malignancy. There have been reports of this paraneoplastic condition's association with orocutaneous papillomatosis, but investigations into its relationship with diffuse esophageal papillomatosis are scarce. We report a case of acanthosis nigricans with tripe palms that was associated with diffuse esophageal squamous papillomatosis. A 40-year-old Thai woman with underlying systemic lupus erythematosus and secondary Sjögren's syndrome, who was recently diagnosed with acanthosis nigricans and tripe palms was investigated for occult gastrointestinal malignancy. An upper $\mathrm{Gl}$ endoscopy revealed diffuse squamous papilloma along the entire esophagus and lower $\mathrm{Gl}$ endoscopy revealed one pedunculated hyperplastic polyp $1 \mathrm{~cm}$ in size at the sigmoid colon. Long-term follow-up is needed to reassure these coexisting conditions belonging to benign systemic diseases without hidden malignancy.




\section{Case Reports in Gastroenterology}

\begin{tabular}{l|l}
\hline Case Rep Gastroenterol 2020;14:702-706 \\
\hline DOI: 10.1159/000511251 & $\begin{array}{l}\text { ○ 2020 The Author(s). Published by S. Karger AG, Basel } \\
\text { www.karger.com/crg }\end{array}$ \\
\hline
\end{tabular}

Chantarojanasiri et al.: Diffuse Esophageal Squamous Papillomatosis: A Rare Disease Associated with Acanthosis Nigricans and Tripe Palms

\section{Introduction}

Esophageal squamous papilloma (ESP) is a rare benign esophageal lesion [1, 2]. Most lesions are solitary [2,3]; nonetheless, diffuse esophageal squamous papillomatosis involving the entire esophagus is extremely rare. Acanthosis nigricans (AN) with tripe palms is a wellknown skin manifestation of systemic conditions, as well as internal malignancy [4]. There have been reports of this paraneoplastic condition's association with orocutaneous papillomatosis, but investigations into its relationship with diffuse esophageal papillomatosis are scarce. Here, we reported an unusual case of diffuse esophageal squamous papillomatosis associated with AN and tripe palms.

\section{Case Presentation}

A 40-year-old Thai woman with underlying systemic lupus erythematosus and secondary Sjögren's syndrome attended the dermatology department for skin lesions and consulted the gastroenterology department with suspected occult gastrointestinal malignancy. She presented 18 months ago with a diffuse brownish hyperpigmentation and velvety thickening of the skin in the axillae and posterior neck. No history of dysphagia, odynophagia, heartburn, change in bowel habit, or weight loss was noted, and she appeared generally well. Physical examination revealed skin thickening and hyperpigmentation of the axillae and posterior neck with a velvety appearance (Fig. 1a), and her palms and soles were thickened and rough (Fig. 1b). Hyperplastic and papillomatous changes of the lips and oral cavity were also noted (Fig. 1c). Initial laboratory tests were unremarkable and chest $X$-ray was within normal limits. Diagnosis of AN and tripe palms was made, and investigations for occult gastrointestinal malignancy were initiated.

An upper GI endoscopy was performed and revealed diffuse circumferential whitish-pink, wart-like exophytic projections with friable mucosa together with contact bleeding along the entire esophagus (Fig. 2a). Forceps biopsy was performed, and the pathology results were consistent with squamous papilloma without evidence of dysplasia or carcinoma (Fig. 2b). Lower GI endoscopy revealed one pedunculated polyp $1 \mathrm{~cm}$ in size at the sigmoid colon, and this was removed by hot snare polypectomy, with subsequent pathology results consistent with a hyperplastic polyp.

Three months later, the patient came to follow-up in the outpatient clinic and showed no significant gastrointestinal symptoms. Further investigations for occult internal malignancy were planned but have not yet been performed because of the COVID-19 pandemic.

\section{Discussion}

ESP is a rare benign esophageal lesion with a total incidence of $0.01-0.04 \%$ of all upper GI endoscopies $[1,2]$. Most lesions are solitary and the majority of patients are asymptomatic $[2,3]$, and diffuse esophageal squamous papillomatosis involving the entire esophagus is extremely rare. On endoscopy, the lesions appear as whitish-pink, wart-like exophytic projections (Fig. 2a). The etiology of ESP is not fully understood, although there are two possible hypothesized reasons: infection with human papillomaviruses [5] and chronic mucosal

\section{Karger'=}




\section{Case Reports in Gastroenterology}

\begin{tabular}{l|l}
\hline Case Rep Gastroenterol 2020;14:702-706 \\
\hline DOI: 10.1159/000511251 & $\begin{array}{l}\text { @ 2020 The Author(s). Published by S. Karger AG, Basel } \\
\text { www.karger.com/crg }\end{array}$ \\
\hline
\end{tabular}

Chantarojanasiri et al.: Diffuse Esophageal Squamous Papillomatosis: A Rare Disease Associated with Acanthosis Nigricans and Tripe Palms

irritation, such as acid reflux, prolonged use of nasogastric tube, metal stent insertion, smoking, or alcohol use.

Most cases of ESP are asymptomatic [6], and its clinical causes vary from spontaneous regression to the development of squamous cell carcinoma [7]. Owing to the paucity of case reports, there are no standard therapeutic or surveillance guidelines for its treatment or follow-up. Treatment modalities include biopsy, excisional biopsy, mucosectomy, argon plasma coagulation [7], and cryoablation [8].

AN is a well-known skin manifestation of systemic conditions. It appears as a thickening hyperpigmentation, with velvety texture of the skin, mainly involving skin folds, particularly in the neck and axilla [4]. Although most cases of AN are associated with obesity and insulin resistance, other causes have been described, with paraneoplastic AN being the most worrisome condition. Presence of pruritus, especially with rapid onset, indicates paraneoplastic AN, which is usually associated with intra-abdominal or genitourinary malignancy [4]. In many reported cases of AN associated with gastric carcinoma, esophagogastric carcinoma, or biliary carcinoma, the onset of skin lesions usually precedes the local symptoms of the malignancy by several months [9-11].

AN can also involve the esophagus in the form of granular nodules through the length of the esophagus [9]. Endoscopy shows multiple papillary-protruded lesions with white apices in the entire esophagus mucosa. Histological features of these lesions are epithelial hyperplasia and papillomatosis [12], which is pathologically different from ESP [13]. AN in association with diffuse ESP has been reported in which no other malignancy was found during 7 years of follow-up [14].

We report an unusual case of diffuse esophageal squamous papillomatosis with AN and tripe palms. Unfortunately, the investigation for hidden malignancy has not yet been completed and long-term follow-up is needed to reassure these coexisting conditions belonging to benign systemic diseases.

\section{Acknowledgements}

The authors would like to thank Dr. Titaporn Nopmaneepaisarn for reviewing pathology and taking a photo of the specimen of this case report.

\section{Statement of Ethics}

This case report was approved by the ethics committee of Rajavithi Hospital (No. 63155) and written informed consent was obtained from the patient for publication of this case report and any accompanying images. The committees use the Declaration of Helsinki ethical principles and the International Conference on Harmonization in Good Clinical Practice.

\section{Conflict of Interest Statement}

The authors declare that they have no competing interests.

\section{Karger'}




\section{Case Reports in Gastroenterology}

\begin{tabular}{l|l}
\hline DOI: 10.1159/000511251 & @ 2020 The Author(s). Published by S. Karger AG, Basel \\
\hline
\end{tabular}
www.karger.com/crg

Chantarojanasiri et al.: Diffuse Esophageal Squamous Papillomatosis: A Rare Disease Associated with Acanthosis Nigricans and Tripe Palms

\section{Funding Sources}

None.

\section{Author Contributions}

T.C., A.B., and A.S. were responsible for the study concept and design, data collection, discussion, and drafting of the manuscript. T.C. and A.S. reassessed the contents and English grammar of the manuscript. A.S. supervised the whole process of the study. All authors read and approved the final manuscript.

\section{References}

1 Szántó I, Szentirmay Z, Banai J, Nagy P, Gonda G, Vörös A, et al. [Squamous papilloma of the esophagus. Clinical and pathological observations based on 172 papillomas in 155 patients]. Orv Hetil. 2005 Mar;146(12):547-52.

2 Mosca S, Manes G, Monaco R, Bellomo PF, Bottino V, Balzano A. Squamous papilloma of the esophagus: longterm follow up. J Gastroenterol Hepatol. 2001 Aug;16(8):857-61.

3 Carr NJ, Monihan JM, Sobin LH. Squamous cell papilloma of the esophagus: a clinicopathologic and follow-up study of 25 cases. Am J Gastroenterol. 1994 Feb;89(2):245-8.

4 Popa ML, Popa AC, Tanase C, Gheorghisan-Galateanu AA. Acanthosis nigricans: to be or not to be afraid. Oncol Lett. 2019 May;17(5):4133-8.

5 Poljak M, Orlowska J, Cerar A. Human papillomavirus infection in esophageal squamous cell papillomas: a study of 29 lesions. Anticancer Res. 1995 May-Jun;15(3):965-9.

6 Ölmez Ș, Aslan M, Güdücüoğlu H, Erten R, Taș A, Sarıtaș B. Esophageal squamous papillomatosis. Wien Klin Wochenschr. 2016 Jun;128(11-12):447-9.

7 d'Huart MC, Chevaux JB, Bressenot AM, Froment N, Vuitton L, Degano SV, et al. Prevalence of esophageal squamous papilloma (ESP) and associated cancer in northeastern France. Endosc Int Open. 2015 Apr;3(2):E101-6.

8 Alomari M, Wadhwa V, Bejarano P, Amar P, Erim T. Successful Treatment of Extensive Esophageal Squamous Papillomatosis With Cryotherapy. ACG Case Rep J. 2019 Mar;6(3):1-4.

9 Sarbia M, Ringelhan M, Siveke J, Bettstetter M, Karimi D. [Paraneoplastic acanthosis nigricans of the esophagus: a case report]. Z Gastroenterol. 2012 Jul;50(7):680-3.

10 Yu Q, Li XL, Ji G, Wang Y, Gong Y, Xu H, et al. Malignant acanthosis nigricans: an early diagnostic clue for gastric adenocarcinoma. World J Surg Oncol. 2017 Nov;15(1):208.

11 Rizwan M, Iftikhar N, Sarfraz T, Ullah O. Malignant Acanthosis Nigricans: An Indicator of Internal Malignancy. J Coll Physicians Surg Pak. 2019 Sep;29(9):888-90.

12 Mignon FC, Laroche L, Revuz J, Chatel A, Cattan D, Bader JP. [Acanthosis nigricans associated with diffuse esophageal papillomatosis]. Nouv Presse Med. 1975 Oct;4(35):2507-10.

13 Sablich R, Benedetti G, Bignucolo S, Serraino D. Squamous cell papilloma of the esophagus. Report on 35 endoscopic cases. Endoscopy. 1988 Jan;20(1):5-7.

14 Amano T, Nishida T, Inada M. Diffuse esophageal papillomatosis in a patient with acanthosis nigricans. Dig Endosc. 2016 Sep;28(6):685. 

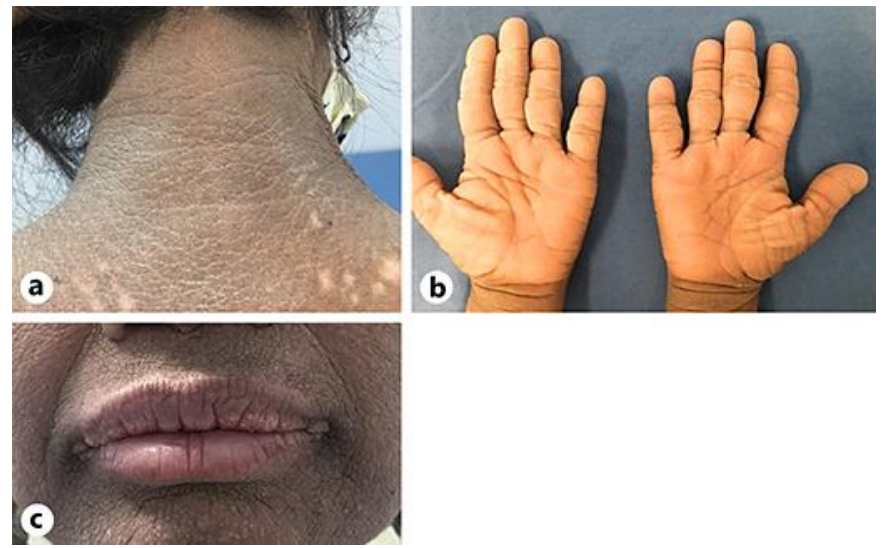

Chantarojanasiri et al: Diffuse Esophageal Squamous Papillomatosis: A Rare Disease Associated with Acanthosis Nigricans and Tripe Palms

Fig. 1. Physical examination revealed velvety hyperpigmentation of the skin (a), thickening palms and soles (b), and papillomatous changes of the lips and oral cavity (c).
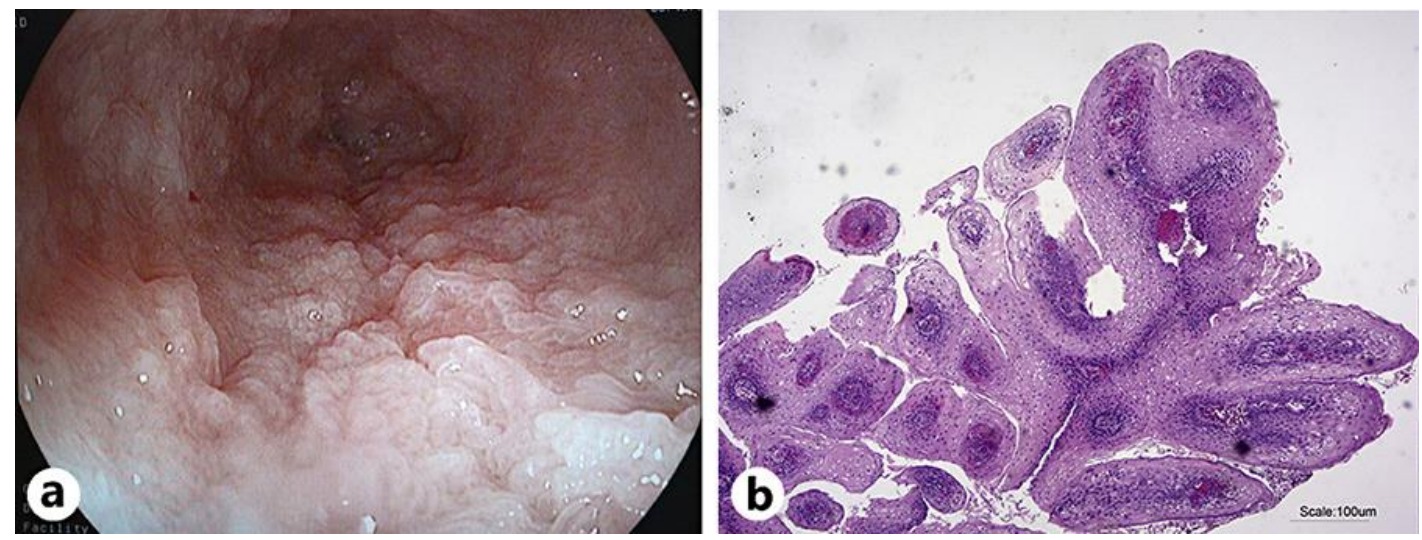

Fig. 2. Upper GI endoscopy showed diffuse circumferential whitish-pink, wart-like exophytic projections with friable mucosa (a). Forceps biopsy results were consistent with squamous papilloma (b). 